\title{
Swami Vivekananda on India as a Nation
}

\author{
Amit Kumar Raul \\ Assistant Professor and Head, Dept. of English, K. D. College of Commerce and General Studies \\ (Affiliated to Vidyasagar University), P.O.: Midnapore, Dist.: Paschim Medinipur, Pin: 721101 \\ W. B., India
}

\begin{abstract}
Nation is a political concept and originated in the West. Ernest Renan's "What is a Nation?" is generally regarded as the first discourse on the Western concept of modern nation. Later many theorists have developed the theories of nation, which is a social construct, by experiencing the emergence of various nations till recent past. Nation is ultimately the will for self-determination and it is intimately connected to state. This overtly political concept of nation was strongly debated by Vivekananda in India who foregrounded Vedantic nationalism as an alternative concept / model against the dominating Western ideology. Though Vivekananda's ideas have mostly remained as redundant in India and abroad, a critical re-examination of his India as a nation may be a fitting tribute to him in his sesquicentennial birth anniversary. This endeavour is also important from the postcolonial perspectives. To our astonishment it is found that his theory of nation is unique, modern and as contemporary as the recent theories of nation. His blending of religion and science, Western materialism and Eastern spiritualism, man-making religion, character-building education, etc. are path-breaking and beneficial ideas not only to future India but also to the mankind in general. In Vivekananda the Eastern and the Western paradigms of nation happily fuse for real prosperity of man.
\end{abstract}

Keywords - India, Nation, Political concept, Vedantic nationalism, Vivekananda

The concept of modern nation originated in the West. It is generally agreed that the advent of modern nation is first noticed in the First Partition of Poland (1775), in the American Declaration of Independence (1776), in the French Revolution (1789), etc. Any discussion on the Western concept of nation generally starts with Ernest Renan who, on March 11, 1882, in a lecture entitled, "What is a Nation?", delivered at the Sorbonne, Paris, while articulating the idea of nation in the aftermath of the defeat suffered by France in the France-Prussian War of 1871 , very lucidly said:

A nation is a soul, a spiritual principle. Two things, which in truth are but one, constitute this soul or spiritual principle. One lies in the past, one in the present. One is the possession in common of a rich legacy of memories; the other is present-day consent, the desire to live together, the will to perpetuate the value of the heritage that one has received in an undivided form. [1]

In the last part of his lecture, Renan summed up:

Man is a slave neither of his race nor of his language, nor of his religion, nor of the course of rivers, nor of the direction taken by mountain chains. A large aggregate of men, healthy in mind and warm of heart, creates the kind of moral conscience which we call a nation. [2]

Nation is 'a large scale solidarity' [3] sustained by history / past codified in memory and amnesia purposely or otherwise. Renan identifies nation as a form of 'moral conscience' [4] and its existence is a 'daily plebiscite' [5]. Thus, a nation is a community of people whose members are bound together by a sense of solidarity / oneness, a common culture / heritage, a national consciousness, etc.

Later many theorists have propounded competing definitions and confounding assumptions underlying the concept of nation by looking at the perplexing varieties involved in the formation of no less than 192 nations (till 2006). Hence, any clear-cut, comprehensive idea of it is almost impossible though certain basic features may be enumerated that make up the essence of the concept we call nation. Nation takes its birth due to any number of the subjective and objective factors like language, territory, race, religion, political entity, common descent, customs and tradition, culture, power, soul or living and active corporate will, communication, etc. As a form of collective identity nation is different from other collective identities like caste, region and religious community though, sometimes, the former attachment slides into the latter ones. Nationalism is what a nation does or promulgates. In the name of the nation, nationalism involves the process of institutionalizing and legitimizing the same and defends and defines its boundaries. Most theorists use these two terms, i.e. 'nation' and 'nationalism', interchangeably. However, the political aim of self-determination is the most distinguished mark of a Western nation as nation is ultimately a commitment to a political project.

This modern / political notion of Western nation was altogether new on Indian soil in the colonial era and hence vehemently clashed with the indigenous / spiritual idea of civilizational nation prevalent in the East. 
In the context of the West's unceasing attempt to disparage the East, it was a dire need of defending one's own nation / culture / heritage and of giving an alternative model / notion of nation to the West. Swami Vivekananda's importance lies in the fact that he was the first who conceptualized and theorized in clearest terms the Eastern concept of nation / nationalism based on religion / spirituality and championed its superiority over the Western notion of political nation. Subhas Chandra Bose regarded him "as the spiritual father of the modern nationalist movement" [6]. Nehru considered Vivekananda as "one of the great founders ...of the national modern movement of India" [7]. Tagore and Gandhi were also great admirers of Vivekananda. Hence, it becomes interesting to ponder a while on Swami Vivekananda's India as a nation and the relevance of his concept during the emergence of India as a nation on the lines of Western politics. The paper would specifically explore this.

Unlike Ram Mohan Roy, Keshav Chandra Sen, Gokhale and others who believed in Europe's political / civilizing mission to India, Vivekananda, like Dayananda, Gandhi and others, believed in India's spiritual superiority and mission to the materialistic West. He laid the foundation stone of religious theory of nationalism, which is also known as Vedantic nationalism, in India that was later propagated by many like Bipin Chandra $\mathrm{Pal}$, Aurobindo and others. According to Vivekananda, each nation has at least one unifying principle. India's is religion:

Let others talk of politics, of the glory of acquisition of immense wealth poured in by trade, of the power and spread of commercialism, of the glorious fountain of physical liberty; but these the Hindu mind does not understand and does not want to understand. Touch him on spirituality, on religion, on God, on the soul, on the Infinite, on spiritual freedom, and I assure you, the lowest peasant in India is better informed on these subjects than many a so-called philosopher in other land. . . We have yet something to teach to the world. [8]

In 1880s, Vivekananda realized this in his bharatparikrama (travel throughout India) and in the company with his master Sri Ramakrishna. Deepest religious and moral urges of the people, rather than political ideal, would be the basis of India as a nation. The spiritual past of India would act as the unifying force in building up the nation and would be a gift of India to the West. Spirituality or religion had no orthodox or narrow implication to Vivekananda. By these, he meant eternal human values and moral and spiritual advancement. Vivekananda considered the Vedanta as the greatest treasure-house of rational explanations for forging a modern nation. References may be made to its teachings of faith in oneself, of oneness of all living beings, of the divinity of man, of disinterested action, of tolerance, etc. This concept of Vedantic nationalism is to be regarded as Vivekananda's unique and alternative theory formulated quite surprisingly at a time when the Western theorist Renan delivered his idea of nation in Paris. Vivekananda's insistence on reclaiming the pristine glory or rich heritage of the past, religion / spirituality in the case of India, for creating national consciousness has later been echoed and theorized in Fanon's The Wretched of the Earth (1963) where so much emphasis has been given on making the age-old tradition dynamic and responsive to the present-day need of forging we-feeling and togetherness for anti-colonial nationalist struggles [9].

In the colonized location, Vivekananda, though not politically, redefined the word 'freedom' and gave an altogether new connotation to it. He believed in multiple layers of human existence. Accordingly, 'freedom' had a larger meaning to him. It stood for physical, mental, moral, intellectual and spiritual freedom. Being a spiritual leader he solely protested against "the mind-forg'd manacles" [10] and spoke of man-making religion. He condemned weakness and tried all through his life to inculcate fearlessness and strength in his fellow countrymen. Though he consciously avoided the then politics against the British imperialism, these attempts of Vivekananda may be considered as his protest against cultural and psychological colonization which has later been theorized by N'gugi in Decolonising the Mind [11] and many others. Thus, he obliquely formulated the theory of anti-colonial resistance:

The essence of my religion is strength. The religion that does not infuse strength into the heart, is no religion to me, be it of the Upanishads, the Gita, or the Bhagvatam. Strength is greater than religion and nothing is greater than strength. [12]

He wanted to make Hinduism aggressive and build characters by cultivating the spirit of lions in them.

Vivekananda opined, "strength must come to the nation through education" [13]. He wanted to build character through education. Though the nation is a collective identity, he gave sole importance on the constituent individuals as the character of the later would determine the nature and fate of the nation. Vivekananda identified two great ideals of Indian civilization, i. e. service to man and emancipation / salvation for the individual, as the moral foundations of national comradeship which an individual must learn and imbibe with utmost sincerity. Hence, he made a passionate call to all Indians, particularly the youth of India, in the following manner which is popularly known as his Swadesh Mantra:

Thou brave one be bold, take courage, be proud that thou art an Indian, and proudly proclaim, 'I am an Indian, every Indian is my brother'. Say, 'The ignorant Indian, the poor and destitute Indian, the Brahmin Indian, the pariah Indian, is my brother.' Thou, too, clad with but a rag round thy loins, 
proudly proclaim at the top of thy voice: 'The Indian is my brother, the Indian is my life, India's gods and goddesses are my God, India's society is the cradle of my infancy, the pleasure-garden of my youth, the sacred heaven, the Varanasi of my old age.' Say, brother: 'The soil of India is my highest heaven, the good of India is my good,' and repeat and pray day and night, 'O Thou Lord of Gouri, O Thou Mother of the Universe, vouchsafe manliness unto me ! O Thou Mother of Strength, take away my weakness, take away my unmanliness, and Make me a Man! [14]

This inspired call, though written in prose, of Vivekananda to Indians can be placed beside Bankim's Bande Mataram or Tagore's Jana Gana Mana Adhinayaka as far as imagining the nation and creating feeling for the nation are concerned. He did not blame religion but men. Men must be given proper education not to think of personal comfort or salvation but to raise and serve the masses taking them as gods, as no political uplift was possible without the uplift of the masses. Vivekananda, in fact, invented the fifth form of Yoga, i. e. Seva-Yoga, to the already existing Raja-Yoga, Jnana-Yoga, Karma-Yoga and Bhakti-Yoga for attaining God and thus enriched the Indian philosophic tradition and made it dynamic and responsive to the need of India's anticolonial nationalist struggles. So, he firmly believed that spiritual values rather than political ideas would rescue India.

Vivekananda dreamt of a classless and casteless Indian nation and propagated the theory of a society / community of "an Islamic body with Vedantic brains" [15]. He welcomed Western science and technology to eradicate poverty, hunger from society and save the starving masses. The Indian way of life badly needed materialistic support of the West while the latter needed the spiritual values from the East. This interdependence and co-ordination between the Orient and the Occident was largely popularized by Vivekananda for the true development of mankind in general. This science-religion nexus may be considered as a unique contribution of Vivekananda to the process of nation-building. Vivekananda, however, did not believe in centre / periphery binary as he liked multi-racial and multi-religious conglomeration, as he looked forward to a nation upholding "unity in diversity". He was the true embodiment of tolerance, freedom and strength, service and renunciation.

There is no denying the fact that he has had an irresistible impact on the later generations of nationalists, politicians and citizens before and after India's independence. A glimpse of it has already been given. Here, I feel tempted to quote the words of the first Prime Minister of India, Jawaharlal Nehru, who eloquently praised him:

Rooted in the past and full of pride in India's prestige, Vivekananda was yet modern in his approach to life's problems and was a kind of bridge between the past of India and her present. [16]

Even in his sesquicentennial birth anniversary in 2012, Vivekananda and his call to the nation is remembered and observed with due respect, pomp and glory throughout India. He has been projected as the leader of the youth and his birthday is observed as World Youth Day.

Yet, to the utter surprise of all, Vivekananda's ideals and motto have been kept aside consistently while framing political strategies for the uplift of Indian nation. He is never considered as a serious political theorist in disguise. The tradition of ignoring Vivekananda's ideas of India as a nation began with Amvika Charan Mazumdar's Indian National Evolution (1915), Surendranath Banerjee's A Nation in Making (1925) and Bipin Chandra Pal's Swadeshi and Swaraj (1954) where no influence of Vivekananda on Swadeshi Movement or on the rise of nationalism in Bengal was mentioned. The tradition still continues. Some considered him as a Hindu revivalist, not a political theorist of nation, and hence an outcast to the modern concept of nation. The contemporary nationalist leaders' reason for remaining indifferent to Vivekananda as a political theorist of Indian nation is their pseudo-worship of secularism and misreading of Vivekananda's theory of Vedantic nationalism. To the present-day citizens, secularism is akin to anti-religion and something far from Vedanta. And so Vivekananda does not come within the purview of the discussion on political nationalism. He is irrelevant to the modern form of governance and process of nation-building.

But the paradox lies in the fact that Vivekananda's idea of religion / spirituality is secular, allembracing, rational and more modern than the modern concept of political nation itself. We have traditionally developed a fixed notion of reading Vivekananda as a spiritual leader of India and his ideas as merely having moral and spiritual values. He avoided politics and state power for being a sanyasin but believed in a political organization as a must for a nation. His writings and speeches bear testimony to the modern concept of nation which is unique and, at times, nearer to that of the Western theorists of nation like Renan, Fanon, N'gugi and others. He is worthy of being rightly considered as the first and foremost fiery orator of anti-colonial resistance in India. Vivekananda's Lectures from Colombo to Almora may also be valued as his political testament to the Indian nation. Thus, Vivekananda is extremely important and relevant from the contemporary postcolonial perspectives and his idea of nation with reference to India is a fine amalgam of the Eastern and the Western paradigms of nation. 


\section{References}

[1] Ernest Renan, "What is a nation", in Homi K. Bhabha (Ed.), Nation and Narration, (London: Routledge, 1990, Rpt., 1995$) 19$.

[2] Ibid., 20.

[3] Ibid., 19.

[4] Ibid., 20.

[5] Ibid., 19

[6] Quoted in Swami Vivekananda, My India: The Eternal India, (Kolkata: R. K. Mission Inst. of Culture, 1993, Rpt. 2008) 209.

[7] Ibid., 208

[8] Swami Vivekananda, My India: The Eternal India, (Kolkata: R. K. Mission Inst. of Culture, 1993, Rpt. 2008$) 17$.

[9] Frantz Fanon, The Wretched of the Earth, Tr. Constance Farrington, (New Delhi: Penguin, Rpt., 2001).

[10] William Blake, "London", in D. Sengupta and S. Cama (Ed.), Blake, Wordsworth and Coleridge, (Delhi: Worldview, 2008$) 75$.

[11] N'gugi wa Thiong'o, Decolonising the Mind, (Oxford: James Curry Ltd., 1997 Rpt.).

[12] Quoted in V. P. Verma, Modern Indian Political Thought, (Agra: Lakshmi Narain, 2009, Rpt.) 116.

[13] Ibid., 116.

[14] Swami Vivekananda, My India: The Eternal India, (Kolkata: R. K. Mission Inst. of Culture, 1993, Rpt. 2008$) 20$.

[15] Ibid., 11

[16] Quoted in Swami Vivekananda, My India: The Eternal India, (Kolkata: R. K. Mission Inst. of Culture, 1993, Rpt. 2008$) 206$.

\section{About The Author}

Mr. Amit Kumar Raul is an Assistant Professor (Stage-3) \& Head, Dept. of English, K. D. College of Commerce and General Studies, (affiliated to Vidyasagar University), Midnapore, W. B., India. At present he is working on the novels of Mulk Raj Anand and Raja Rao for earning his doctoral degree. His areas of interest include Dalit Studies, Indian English, British, American, Comparative and Postcolonial Literatures. He has presented papers in numerous national seminars and published papers in different journals of repute. He has completed a UGC Research Project on the representation of the Dalits in Indian English writings and is presently working on a second UGC Research Project. 